\title{
DEVELOPING A PERFORMANCE EVALUATION SCHEME FOR ENGINEERING FACILITIES IN COMMERCIAL BUILDINGS: STATE-OF-THE-ART REVIEW
}

\author{
Joseph H. K. LAI a,*, Chun Sing MAN a \\ ${ }^{a}$ Department of Building Services Engineering, The Hong Kong Polytechnic University, Hung Hom \\ Kowloon, Hong Kong, China \\ Received 19 August 2015; accepted 3 March 2016
}

\begin{abstract}
Various post-occupancy evaluation schemes have been introduced for assessing building performance but one tailored for large-scale commercial buildings remains to be seen. Intended to develop a scheme for evaluating the performance of engineering facilities in existing commercial buildings, a multi-stage study was carried out in a dense-built metropolis - Hong Kong. Reported here is the part of work based on an extensive literature review. Considering the characteristics of relevant evaluation schemes, the requirements for useful performance evaluation and the criteria for selecting key performance indicators (KPIs), an integrated process-hierarchy model was formed for identifying applicable indicators for the intended scheme. A total of 71 indicators, classified into five categories: (i) physical, (ii) financial, (iii) task and equipment related, (iv) environmental, and (v) health, safety and legal, were identified. Their representations and their empirical applications, which are helpful for the strategic management of existing buildings, are also described.
\end{abstract}

KEYWORDS: Assessment scheme; Facility management; Performance indicator; Literature review; Post-occupancy evaluation

\section{INTRODUCTION}

As technology continues to evolve, commercial buildings are increasingly equipped with sophisticated engineering facilities, including those that provide energy supply; fire detection and protection; refrigeration, cooling, heating and ventilation; water supply and drainage; lighting; vertical transportation; communication; security and alarm; and so on (Chartered Institution of Building Services Engineers 2015b). Such facilities not only need to ensure a safe, healthy and comfortable indoor environment but also satisfy the needs and demands of numerous building stakeholders.

In addition to the capital outlay for procuring and installing the facilities, continuous input of resources, which include manpower, energy and materials for their operation and maintenance (O\&M) and for management of the O\&M processes, is required for delivering the services that the facilities provide. To this end, building owners have to make significant investment on O\&M works and, in order to obtain satisfactory return on investment, it is imperative to ensure that the works are costeffective (Lai, Yik 2008; Lai et al. 2008).

* Corresponding author. E-mail: bejlai@polyu.edu.hk
Whereas substantial resources are required for running the facilities, O\&M budgets are often limited (Lai 2010). Priority setting is thus needed for appropriate resources allocation (Riratanaphong, Van der Voordt 2014; Thor 1991; Webster, Hung 1994). Performance evaluation, which allows monitoring the quality of O\&M works and hence identification of any room for improvement (Kincaid 1994; Koleoso et al. 2013; Van Horenbeek, Pintelon 2014), is an essential decision-making tool for facility engineers or managers. Without a proper performance evaluation, on the other hand, it is not possible to realize to what levels the facilities have performed or ascertain whether the levels of resources expended are appropriate. Underperformance of the facilities, if undetected, would affect the operations of buildings, resulting in environmental impacts, financial losses or even legal liabilities.

The scope of facility management (FM) covers a wide spectrum of support services (British Institute of Facilities Management 2015; International Facility Management Association 2015), which may be brought together for the benefit of 
an organization by optimizing the efficiency, cost and quality of the services (Amaratunga 2000). Over the years, much attention has been placed on evaluating the performance of "soft" FM services, e.g. reception and housekeeping (Best et al. 2003; Haktanir, Harris 2005; Ingram, Daskalakis 1999; Min, H., Min, H. 1996, 1997; Min et al. 2002). Assessing the performance of services on the "hard" side of FM, especially engineering facilities, was comparatively uncommon.

While research studies on some performance facets of engineering facilities have started to grow (e.g. Lai 2014; Lai, Yik 2012), a standard scheme designated for evaluating the holistic performance of the facilities in commercial buildings remains unavailable. To address this deficiency, a fourstage study was undertaken in Hong Kong where the commercial buildings, many of them being skyscrapers or mega-scale developments, are equipped with advanced engineering facilities.

In Stage 1 of the study (Fig. 1), as reported in Man et al. (2013), a research framework was formulated and an extensive literature search was made to identify indicators that can reflect the performance of engineering facilities. The subsequent works include: (i) a focus group meeting to

Stage 1

- Identify performance indicators that are usable for the intended performance evaluation scheme

- Categorize the performance indicators

- Shortlist key performance indicators (KPIs) for use in the scheme
Stage 2

- Investigate and confirm levels of usefulness of the KPIs

- Form a framework for the evaluation scheme
Stage 3 (ex-ante scheme establishment)

- Determine importance weights of the KPIs via an analytic network process (ANP)

- Establish the evaluation scheme
Stage 4 (ex-post scheme establishment)

- Determine performance levels of facilities

- Calculate a performance score for the facilities

- Validate the applicability of the scheme

Fig. 1. Overall research process of the study 
shortlist key performance indicators (KPIs) for use in the scheme; (ii) a questionnaire survey in Stage 2 to find out the levels of usefulness of the shortlisted KPIs; and (iii) a series of face-to-face interviews to determine importance weights of the KPIs and hence establish the intended evaluation scheme (Stage 3) as well as to determine performance levels of engineering facilities for validating the applicability of the scheme (Stage 4).

The works for and findings from the literature review, as reported in the following sections, cover key features of the well-known performance evaluation schemes across the world and building-related assessment schemes in Hong Kong, requirements for a useful performance evaluation scheme, criteria for selecting KPIs for use in the scheme, past studies attempting to establish KPIs for evaluating building performance, and formation of a matrix model for identifying performance indicators. The way of categorizing the identified indicators and the empirical applications of the indicators are also described. The remaining works completed under the study, including those in Stages 2 to 4, will be reported in future.

\section{PERFORMANCE EVALUATION SCHEMES FOR BUILDINGS}

According to Innovate UK (2015), worldwide there are at least 95 building performance evaluation tools or methods. A group of them is devised for assessing sustainable building performance (e.g. Building Research Establishment Environmental Assessment Method (BREEAM) of the United Kingdom and Leadership in Energy \& Environmental Design (LEED) of the United States) and another group is tailored for energy assessment (e.g. National Home Energy Rating (NHER) and National Energy Audit Tool (NEAT)). Some performance evaluation schemes are intended for use in existing buildings, with their scopes covering certain operational aspects. The leading schemes of this kind are typically originated from developed countries such as the United Kingdom, the United States, Canada, Australia and New Zealand. A review of the key features of these schemes is shown in the following.

\subsection{United Kingdom}

Back in 1995, the Post Occupancy Review of Building Engineering (PROBE) project, which is a joint venture funded by the Department of Environment, Transport and the Regions of the UK Government, The Builder Group and publishers of Building Services Journal - now the CIBSE Journal, was commenced (Chartered Institution of Building Services Engineers 2015a). Under the PROBE studies, post-occupancy surveys of well-regarded new commercial and public buildings were carried out to provide feedback on generic and specific information on factors for success in the design, construction, operation and use of buildings (Cohen et al. 2001). The two tools used for a PROBE study are: (i) the occupant survey method developed by Building Use Studies Ltd (BUS) to gauge occupant satisfaction with the building and its internal conditions; and (ii) a prototype of the Energy Assessment and Reporting Method's (EARMTM) Office Assessment Method (OAM) for the analysis of energy use. Typically 10 stages of works are needed to complete a PROBE project: (1) seek and obtain access for study; (2) Pre-Visit Questionnaire (PVQ); (3) first site visit; (4) draft report; (5) second site visit; (6) occupant survey; (7) energy survey; (8) pressure test; (9) report; and (10) probe article. After completing a series of PROBE projects, Bordass et al. (2001) pointed out that the pressures to improve the UK building industry, at the time, focused on production rather than performance in use. More effort on performance evaluation, therefore, is needed to tackle problems of buildings-in-use.

\subsection{United States and Canada}

In the 1980s, work started to create and standardize tools and methods to assess quality and functionality of workplaces and, as a result, the Serviceability Tools and Methods (STM) was developed in Canada (International Centre for Facilities 2000). Dealing with both occupant requirements (demand) and serviceability of buildings and facilities (supply) (Bluyssen 2009; Davis et al. 1993a, 1993b), STM is grounded on a conceptual framework of performance based building (Szigeti, Davis 2005) and it comprises two parts of assessment. One part is used for setting occupant requirements for functionality and quality; the other for assessing the capability of a building to meet those levels of need. Over 100 topics and 340 building features are assessed on both the supply and demand sides using a scale from 1 to 9 .

The STM evaluation kit was approved as part of the American Society for Testing and Materials (ASTM) Standards (American Society for Testing and Materials International 2009). Focusing on the level of facilities services in the post-occupancy stage of buildings, the ASTM Standards for Whole Building Functionality and Serviceability provide a broad- 
brush methodology for performance evaluation (Rimbalová, Vilčeková 2013; Szigeti, Davis 2001).

In the United States, the National Center for Energy Management and Building Technologies developed an Operation and Maintenance Rating System (OMRS) for commercial buildings (Prill et al. 2009). OMRS provides a metric for building occupant satisfaction, energy performance and walk-through performance assessments, and five building performance parameters are assessed: (i) optimized operation and maintenance (in particular for heating, ventilation and air-conditioning system); (ii) building energy use; (iii) occupant survey of building performance; (iv) routine building walk-through performance assessment; and (v) recommendations for advanced building performance management. Basically the parameters are assessed in the form of checklists, leading to a scorecard. But further development of the system is required because an effective scoring method for the fifth parameter was not yet available.

\subsection{Australia and New Zealand}

Developed in Australia and New Zealand for assessing what a building provides in terms of facilities, the Building Quality Assessment (BQA) is an evaluation scheme aimed at ensuring that building owners can accurately identify the needs of occupiers (Ballesty 1999; Clift 1996). A total of 138 factors to be assessed are classified into nine categories; the first seven categories are concerned with the level of services that the building provides and the other two are about maintaining the level of services. The categories are subdivided into sections that represent broad groupings of attributes concerned. Each of the factors is rated by a trained assessor on a scale from 0 to 10 in a descriptive approach according to the corresponding level of provision achieved (McDougall et al. 2002). The categories and factors are prioritized by a weighting system. The score $(0-10)$ of each factor is multiplied by a weight $(0-100)$ that reflects the importance of the factor. The weighted factor scores are summed for each category and normalized by the sum of the weights for the respective category to obtain a category score that is also weighted to reflect the importance of the category. An overall BQA score for a particular building can be obtained by aggregating all the category scores. The key aspects/attributes covered by this scheme (BQA) as well as those of STM and OMRS are summarized in Table 1.

Table 1. Key elements of selected evaluation schemes

\begin{tabular}{|c|c|c|c|}
\hline Schemes & $\begin{array}{l}\text { Building Quality Assessment } \\
\text { (BQA) }\end{array}$ & $\begin{array}{l}\text { Serviceability Tools and Meth- } \\
\text { ods (STM) }\end{array}$ & $\begin{array}{l}\text { Operation and Maintenance } \\
\text { Rating System (OMRS) }\end{array}$ \\
\hline Aspects/attributes & $\begin{array}{l}\text { (1) presentation } \\
\text { (2) space functionality } \\
\text { (3) access and circulation } \\
\text { (4) amenities } \\
\text { (5) business services } \\
\text { (6) working environment } \\
\text { (7) health and safety } \\
\text { (8) structural } \\
\text { (9) building management }\end{array}$ & $\begin{array}{l}\text { (1) support for office work } \\
\text { (2) meetings and group effec- } \\
\text { tiveness } \\
\text { (3) sound and visual environ- } \\
\text { ment } \\
\text { (4) thermal environment and } \\
\text { indoor air } \\
\text { (5) typical office information } \\
\text { technology } \\
\text { (6) change and churn by occu- } \\
\text { pants } \\
\text { (7) layout and building factors } \\
\text { (8) protection of occupant as- } \\
\text { sets } \\
\text { (9) facility protection } \\
\text { (10) work outside normal hours } \\
\text { or conditions } \\
\text { (11) image to public and occu- } \\
\text { pants } \\
\text { (12) amenities to attract and } \\
\text { retain staff } \\
\text { (13) special facilities and tech- } \\
\text { nologies } \\
\text { (14) location, access and way } \\
\text { finding } \\
\text { (15) structure, envelope and } \\
\text { grounds } \\
\text { (16) manageability } \\
\text { (17) management of operations } \\
\text { and maintenance } \\
\text { (18) cleanliness }\end{array}$ & $\begin{array}{l}\text { (1) optimized operation and } \\
\text { maintenance } \\
\text { (2) building energy use } \\
\text { (3) occupant survey of building } \\
\text { performance } \\
\text { (4) routine building walk- } \\
\text { through performance as- } \\
\text { sessment } \\
\text { (5) recommendations for } \\
\text { advanced building perfor- } \\
\text { mance management }\end{array}$ \\
\hline
\end{tabular}


Besides the establishment of the above performance evaluation schemes, Stevens et al. (1994) developed a model called the quality-measurement matrix for performance measurement at different project stages, which cover the operation phase of existing buildings. Various post-occupancy evaluation (POE) models have also been introduced (Carpenter, Oloufa 1995) and the principles of POEs have been well-recognized (Baird et al. 1995; Preiser et al. 1988). An extension of POE is facility performance evaluation (FPE), which is a continuous process of evaluating the performance of one or more aspects of buildings (Zimring 2014). With no standardized methods for conducting an FPE, research initiatives have emerged to develop methods for evaluating FM performance, e.g. for residential buildings (Lai 2012; Lai, Yik 2011) and teaching hotels (Lai, Choi 2015). A new approach of using POE results embedded in building information modeling (BIM) has also been adopted for providing feedback for building performance (Göçer et al. 2015).

\subsection{The Hong Kong situation}

Accommodating more than 7 million people over a limited land area of $1104 \mathrm{~km}^{2}$, Hong Kong has a remarkably high density of buildings (Census and Statistics Department 2015; The Government of the Hong Kong Special Administrative Region 2015). Being an international business, trade and financial hub in Asia, Hong Kong is also a tourist city attracting over 48 million visi- tors a year (Hong Kong Tourism Board 2013). With such a large number of residents and visitors, it is not difficult to imagine the importance of facilities performance in buildings, especially in commercial buildings where a variety of businesses, entertainments and leisure activities take place. The total stock of commercial buildings, excluding car parking spaces and commercial premises owned by the Housing Authority and the Housing Society (both of them being public bodies), already amounted to $21,865,900 \mathrm{~m}^{2}$, of which $10,983,200 \mathrm{~m}^{2}$ are office premises (Rating and Valuation Department 2014).

Since the late 1990s, several building-related performance evaluation schemes/tools have been introduced in Hong Kong. In 1998, the Energy Efficiency Registration Scheme for Buildings was launched by the Electrical and Mechanical Services Department (EMSD). With specified requirements on energy efficiencies of lighting installations, air conditioning installations, electrical installations, lift and escalator installations, and major retrofitting work, this scheme is used to promote the application of energy efficient technologies to building services systems (Electrical and Mechanical Services Department 2012b, 2012d). Nevertheless, the coverage of this scheme is confined to the design and installation requirements of the installations.

A set of energy end-use data and consumption indicators/benchmarking tools, introduced in 2001, was a further initiative taken by EMSD. The tools

Table 2. Building-related performance evaluation schemes/tools in Hong Kong

\begin{tabular}{|c|c|c|c|}
\hline Title & Focus & Developer/organizer & Year \\
\hline $\begin{array}{l}\text { Energy Efficiency Registration } \\
\text { Scheme for Buildings }\end{array}$ & $\begin{array}{l}\text { Design and installation require- } \\
\text { ments on various building services } \\
\text { installations for energy efficiency. }\end{array}$ & $\begin{array}{l}\text { Electrical and Mechanical Services } \\
\text { Department }\end{array}$ & 1998 \\
\hline $\begin{array}{l}\text { Energy end-use data and } \\
\text { consumption indicators/bench- } \\
\text { marking tools }\end{array}$ & $\begin{array}{l}\text { Energy consumptions of various } \\
\text { types of residential and commer- } \\
\text { cial buildings. }\end{array}$ & $\begin{array}{l}\text { Electrical and Mechanical Services } \\
\text { Department }\end{array}$ & 2001 \\
\hline Intelligent Building Index & $\begin{array}{l}\text { Building design and construction } \\
\text { in accordance with the criteria of } \\
\text { intelligent buildings. }\end{array}$ & $\begin{array}{l}\text { Asian Institute of Intelligent } \\
\text { Buildings }\end{array}$ & 2001 \\
\hline $\begin{array}{l}\text { Comprehensive Environmen- } \\
\text { tal Performance Assessment } \\
\text { Scheme for Buildings }\end{array}$ & $\begin{array}{l}\text { Environmental performance and } \\
\text { sustainability of buildings. }\end{array}$ & Buildings Department & 2001 \\
\hline $\begin{array}{l}\text { Building Quality Index } \\
\text { - Building Health and Hygiene } \\
\text { Index } \\
\text { - Building Safety and Condi- } \\
\text { tions Index }\end{array}$ & $\begin{array}{l}\text { Design and management aspects } \\
\text { of residential buildings in terms } \\
\text { of health and hygiene as well as } \\
\text { building-associated risks and con- } \\
\text { dition problems. }\end{array}$ & $\begin{array}{l}\text { Faculty of Architecture, The Uni- } \\
\text { versity of Hong Kong }\end{array}$ & 2003 \\
\hline $\begin{array}{l}\text { Building Environmental As- } \\
\text { sessment Method Plus }\end{array}$ & $\begin{array}{l}\text { Environmental performance and } \\
\text { sustainability of buildings. }\end{array}$ & $\begin{array}{l}\text { Hong Kong Green Building Council } \\
\text { and BEAM Society Limited }\end{array}$ & 2010 \\
\hline Sustainable Building Index & $\begin{array}{l}\text { Environmental performance and } \\
\text { sustainability of buildings. }\end{array}$ & $\begin{array}{l}\text { Hong Kong Quality Assurance } \\
\text { Agency }\end{array}$ & 2012 \\
\hline
\end{tabular}


were designed for benchmarking energy consumptions of various energy-consuming sectors, which cover commercial buildings. Established through an online energy benchmarking tool, the energy consumption benchmarks in the system allow users to compare their own energy consumption performance with others having similar operational and physical characteristics (Electrical and Mechanical Services Department 2012c).

The Intelligent Building Index (IBI), launched by the Asian Institute of Intelligent Buildings (2012), was intended for assessing intelligent buildings. It measures building performance in terms of 10 quality environmental modules: (1) environmental friendliness; (2) space utilization and flexibility; (3) cost effectiveness; (4) human comfort; (5) working efficiency; (6) safety and security measures; (7) culture; (8) image of high technology; (9) construction process and structure; and (10) health and sanitation. This tool can be used to assess whether the buildings are designed and constructed in accordance with the criteria of intelligent buildings.

The Building Quality Index (BQI) was developed by the Faculty of Architecture of the University of Hong Kong (Ho, Yau 2004; Ho et al. 2005). It comprises two indices, namely the Building Health and Hygiene Index (BHHI) and the Building Safety and Condition Index (BSCI). These two indices assess the design and management aspects of residential buildings in terms of health and hygiene as well as building-associated risks and condition problems. The main focus of these two indices is the quality of living environment.

The Comprehensive Environmental Performance Assessment Scheme for Buildings (CEPAS) was launched by the Buildings Department of the Hong Kong Government (Buildings Department 2006a, 2006b, 2006c, 2006d, 2006e, 2012), the Building Environmental Assessment Method Plus (BEAM Plus) was established jointly by the Hong Kong Green Building Council and the BEAM Society Limited (Hong Kong Green Building Council 2012a, 2012b), and the Sustainable Building Index (SBI) was introduced by the Hong Kong Quality Assurance Agency (Hong Kong Quality Assurance Agency 2012a, 2012b). Common to these three schemes, their focus of evaluation is on environmental performance and sustainability of buildings (Man et al. 2012).

A summary of comparisons between the above schemes/tools is displayed in Table 2. Emphases of the schemes/tools are placed on some performance aspects of facilities in existing buildings, e.g. energy or environmental performance, rather than the holistic performance of engineering facilities.

\section{REQUIREMENTS FOR A USEFUL PERFORMANCE EVALUATION SCHEME}

The performance of engineering facilities may be gauged by: the quantities of physical outputs they produce (e.g. amount of ventilation air or cooling delivered, number of persons transported, etc.); the volume of production against the amount of resources input for their operations; the precision and stability of the indoor environmental conditions that they are able to maintain; or the reliability of the facilities in providing the needed services. The eventual performance of the services delivery process may also be judged by how well the needs of the end users are fulfilled. As such, the performance of engineering facilities in buildings may be assessed from different perspectives. While client and customer satisfactions are critical performance measurement criteria for construction projects (Rashvand, Majid 2014), engineering facilities in existing buildings may change with building functions in response to new owner requirements or organizational revolutions (Then et al. 2004) and their performance may be affected by a variety of endogenous and exogenous factors (e.g. equipment durability, operation intensity). Assessment of facilities performance, therefore, should be a continual and proactive process that responds to multiple criteria and facilitates the planning and implementation of reactive solutions to business challenges (Hopfe et al. 2013; Then 2005).

Performance of facilities determines the condition of services delivered to end users of the facilities. Facilities performance data may be collected through: measurement of some physical parameters (e.g. indoor air temperature provided by an air-conditioning system); collection of end user perceptions (e.g. perceived level of thermal comfort); or a combination of both. Data obtained can be processed to evaluate the performance of the facilities and the resultant findings, if properly conveyed, can serve as valuable feedback information for FM staff at different levels - strategic (e.g. department head), tactical (e.g. manager) and operational (e.g. technician) (British Standards Institution 2006, 2011). Such a performance evaluation schema is depicted by Figure 2 . 


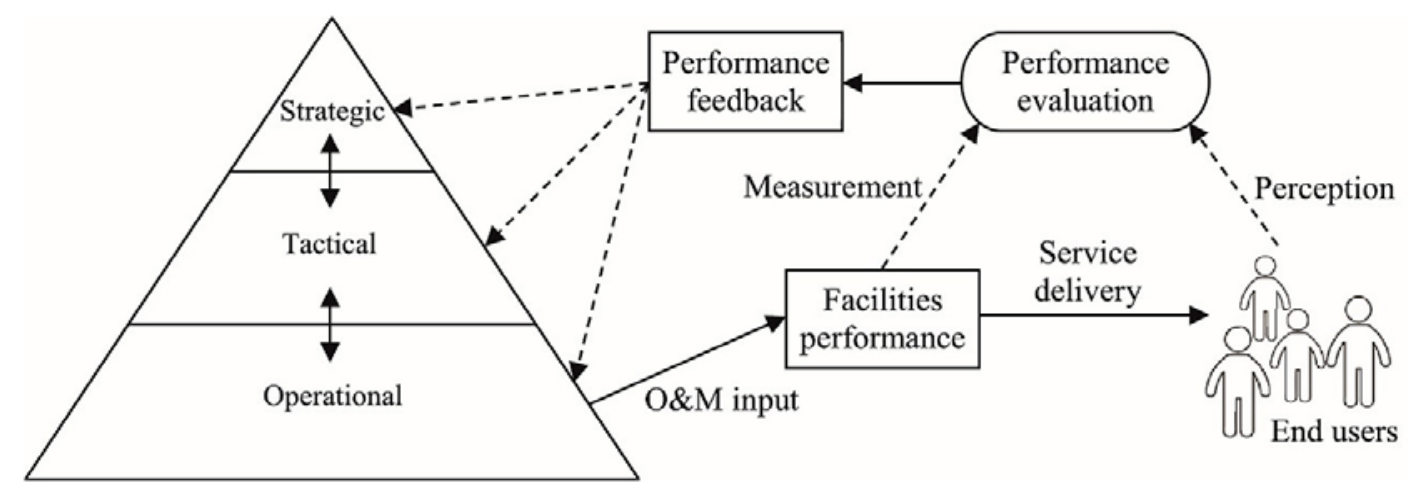

Fig. 2. Information and resources flows in facilities services delivery

Comprehensive performance evaluation could be a complex issue (Parida, Chattopadhyay 2007). Performance evaluation schemes typically cover cost-effectiveness and work efficiency measures (Neely et al. 1995). One for evaluating the performance of engineering facilities should also measure technical aspects including timeliness, productivity and safety (Training Resources and Data Exchange 1995). To allow tracing of accountability, staff involved in the services delivery route should participate in the performance evaluation process (Parida, Kumar 2006). A multi-dimensional and balanced evaluation scheme, in addition, can provide impetus that drives an organization forward (Najmi et al. 2005).

In evaluating facilities performance, as Lai and Yik (2006) pointed out, senior management at the strategic level are more concerned about the outcome resultant from the input resources than the process of services delivery. Cost and income issues are their focuses and they would issue strategies and directions to the lower levels for achieving their organizational goals. Managers at the tactical level, who need to translate the strategies and directions into actions, have to supervise the works of their subordinates. Staff members at the operational level are frontline practitioners who carry out the O\&M works, transforming the input resources into facilities performance.

Although different levels of staff focus on different areas of performance evaluation, the performance result of one level needs to be communicated bilaterally with other levels, in a top-down or bottom-up manner (Parida, Chattopadhyay 2007). Furthermore, a performance evaluation scheme should be developed based on performance metrics measured or calculated at a certain point in time or aggregated over a time period, reflecting not only the past but also the present and the target performance levels in future (British Standards Institution 2011, 2012).
In a nutshell, an effective performance evaluation scheme should be able to recognize different performance hierarchies and multiple dimensions of performance measures. Besides the ability of relating the measures to relevant goals and linking them to appropriate strategies, the scheme should have the power to address cross-functional issues. It is also important to ensure that the scheme gains support from relevant staff and balances different views of the parties involved (Kutucuoglu et al. 2001; Myeda et al. 2011). Close communication among various stakeholders is crucial for enhancing the overall facilities performance (Yusof et al. 2014).

\section{SELECTION CRITERIA FOR KPIS}

KPIs, which can reflect the performance of critical aspects of outputs or outcomes (Chan, A. P. C., Chan, A. P. L. 2004), are essential elements of a performance evaluation scheme. Whereas financial indicators are often desirable, non-financial measures should be included to enable multi-dimensional evaluations (Martinez et al. 2004). For KPIs to be effective, they should be comprehensible, measurable and practical for data collection (Loosemore, Hsin 2001). Being some factors within the control of an organization, KPIs are means that gauge progress toward achieving objectives or other factors that are critical to success (British Standards Institution 2012; Building Services Research and Information Association 2004a).

Suggestions on the selection criteria for KPIs are available in literature; for instance, Carlucci (2010) states that the indicators should be selected in conformance with the following requirements: relevance; reliability; comparability and consistency; and understandability and representational quality. The European Standard BS EN 15341:2007 (British Standards Institution 2007) lays down a series of maintenance KPIs to support management in 
achieving maintenance excellence and utilize technical assets in a competitive manner. The KPIs, which are applicable to various industrial environments and support facilities in buildings, can allow organizations to perform the following functions: (1) measure the status of the facilities; (2) evaluate the performance of the facilities; (3) compare performance internally and with external benchmarks; (4) identify strengths and weaknesses; and (5) control progress and changes over time.

The International Standard BS EN ISO 9004:2009 (British Standards Institution 2009) specifies that KPIs should be able to provide measurable, accurate, reliable and usable information that can assist the implementation of actions to align performance with objectives or improve process efficiency and effectiveness. The information should be able to account for the following: (1) needs and expectations of customers and other interested parties; (2) importance of individual products (services in FM) to the organization both at the present time and in the future; (3) effectiveness and efficient use of resources; (4) profitability and financial performance; and (5) statutory and regulatory requirements, where applicable.

The European Standard BS EN 15221-3:2011 (British Standards Institution 2011) provides that indicators in the performance evaluation scheme should be selected in order to enable the following functions: (1) define objectives/targets to be reached; (2) reflect how well the result meets the demand; (3) indicate at which degree it satisfies the needs/demands and values of all part of client organization as well as provider organization; (4) indicate the status of tasks, processes, operations or projects; (5) compare (internal and external benchmarks); (6) diagnose (analysis of strengths and weaknesses); (7) plan and monitor changes/ development over time; and (8) identify factors that influence performance/quality. Moreover, the Standard lays down a broad range of properties that the indicators should meet, which can be consolidated as: (a) representative and adequate to the context; (b) transparent and repeatable (reproduction of measurement); (c) understandable and tractability of aggregation; (d) high data quality and knowledge about their uncertainty; (e) sensitivity in respect to changes over time; (f) suitability for logging of trends and for comparison; (g) sensitivity in respect to interaction with success factors; (h) relevant in respect to success factors; (i) influential and controllable; (j) availability of data and frequency updatable; and $(\mathrm{k})$ reasonable effort for data gathering.

\section{PAST STUDIES ON IDENTIFICATION OF KPIS}

A significant volume of literature, which covers a wide range of KPIs reflecting different performance aspects of facilities, has been published. Having realized the need of establishing KPIs for FM, the difficulties in setting universally-accepted definitions of the FM function and the lack of existing data for performance evaluation, Hinks and McNay (1999) made use of the Delphi technique to gather expert opinions for identifying appropriate KPIs. Eventually a total of $23 \mathrm{KPIs}$, classified into seven dimensions, were selected for use in the intended management-by-variance tool.

In Hong Kong, Gilleard and Wong (2004) conducted a case study where the analytic hierarchy process (AHP) was applied for FM benchmarking. Involving a FM director who attempted to compare the performance of two service providers using an AHP, seven main criteria of KPIs were identified. In Israel, Shohet (2006) developed an integrated maintenance management model for public acute care hospital facilities, for which 11 KPIs, classified into four categories, were used for the monitoring, management, and maintenance of healthcare facilities. The architecture of the developed model and part of the implementation procedures were elaborated in a subsequent article (Lavy, Shohet 2007).

According to the European Standard BS EN 15341:2007 (British Standards Institution 2007), 71 maintenance KPIs are applicable to industrial and support facilities (e.g. buildings, infrastructure) and they have the functions to help management attain maintenance excellence and utilize technical assets in a competitive manner. Subdivided into three groups, the number of KPIs in each group is: 24 (economic), 21 (technical), and 26 (organizational).

Based on literature survey and interviews conducted in the process and utility industries, Parida and Chattopadhyay (2007) identified a list of important maintenance performance indicators. The performance indicators were grouped under seven criteria of a maintenance performance measurement framework that consists of multi-hierarchical levels of an organization, including corporate/ strategic level, tactical/managerial level and functional/operational level. Besides, the study of Pati et al. (2009) introduced two types of performance indicators - a set based on normative models in biophysics and physiology, the other based on empiricist models of environment-behavior studies. 
The indicators are devised for informing decisions to be made during the design phase as well as the FM stage of a building's lifecycle.

In the United States, Lavy et al. (2010) identified 35 facilities performance indicators based on an extensive literature search on published books, articles in peer-reviewed journals and conference proceedings, assessment reports of federal facilities, benchmarking surveys, and presentations on performance measurements. The indicators were classified into four major categories. Lavy et al. (2014a) continued their work to identify and categorize the core indicators for assessing facility performance. After providing a list of the indictors, Lavy et al. (2014b) derived the equations for calculating the core indicators and discussed the information needed for input to the equations.

The work of Muchiri et al. (2011) in the manufacturing industry classified 31 indicators that can be used for evaluating the performance of maintenance processes. Extracted from literature, the indicators were grouped into two main categories, namely maintenance process (leading) indicators and maintenance results (lagging) indicators. The leading indicators were used to monitor the tasks to be undertaken for attaining desired production results while the lagging indicators were used to measure maintenance results.

In the retail sector, the Professional Retail Store Maintenance Association (2012) published a white paper to provide an overview of retail facilities KPIs to help its members understand the importance of KPIs, provide insight into how the KPIs are used in the industry, and offer a brief guidance on how to establish and administer a KPI programme. According to that paper, the KPIs can be categorized into three main categories, and eight KPIs commonly used by retailers were identified.

With reference to some past studies on operation of buildings, Rimbalová and Vilčeková (2013) identified $37 \mathrm{KPIs}$ in the context of the design and use of sustainable buildings. The KPIs, divided into three groups, were further classified with respect to their impact on core business and relevance to FM services. Table 3 summarizes the essence of this study and the above works, including the methods used for classifying KPIs, number of

Table 3. Past efforts in identifying performance indicators

\begin{tabular}{|c|c|c|c|}
\hline Source & Method & $\begin{array}{l}\text { No. of indi- } \\
\text { cators }\end{array}$ & Categories classified \\
\hline $\begin{array}{l}\text { Hinks and McNay } \\
\text { (1999) }\end{array}$ & Delphi group & 23 & $\begin{array}{l}\text { (1) Business, (2) equipment, (3) space, (4) environment, (5) change } \\
\text { management, (6) maintenance, (7) general }\end{array}$ \\
\hline $\begin{array}{l}\text { Gilleard and Wong } \\
\text { (2004) }\end{array}$ & $\begin{array}{l}\text { Identified by a direc- } \\
\text { tor of FM services of a } \\
\text { property development } \\
\text { company }\end{array}$ & $\begin{array}{l}\text { Not speci- } \\
\text { fied }\end{array}$ & $\begin{array}{l}\text { (1) Financial performance, (2) productivity, (3) project performance, } \\
\text { (4) equipment availability, (5) compliance, (6) complaint and accident } \\
\text { frequency, (7) customer satisfaction }\end{array}$ \\
\hline Shohet (2006) & $\begin{array}{l}\text { KPIs were developed } \\
\text { based on statistical and } \\
\text { quantitative analyses }\end{array}$ & 11 & $\begin{array}{l}\text { (1) Asset development, (2) organization and management, (3) perfor- } \\
\text { mance management, (4) maintenance efficiency }\end{array}$ \\
\hline $\begin{array}{l}\text { British Standards } \\
\text { Institution (2007) }\end{array}$ & $\begin{array}{l}\text { Prepared by a technical } \\
\text { committee }\end{array}$ & 71 & (1) Economic, (2) technical, (3) organizational \\
\hline $\begin{array}{l}\text { Parida and Chat- } \\
\text { topadhyay (2007) }\end{array}$ & $\begin{array}{l}\text { Literature survey and } \\
\text { interviews }\end{array}$ & 28 & $\begin{array}{l}\text { (1) Equipment related, (2) maintenance task related, (3) cost related, } \\
\text { (4) impact on customer satisfaction, (5) learning and growth, (6) } \\
\text { health, safety, security and the environment, (7) employee satisfac- } \\
\text { tion }\end{array}$ \\
\hline Pati et al. (2009) & $\begin{array}{l}\text { Literature review and } \\
\text { scientific formulas for } \\
\text { calculating the indica- } \\
\text { tors }\end{array}$ & 35 & (1) Lighting, (2) thermal comfort, (3) energy, (4) maintenance \\
\hline Lavy et al. (2010) & $\begin{array}{l}\text { Literature review and } \\
\text { a brief survey with } 11 \\
\text { FM professionals }\end{array}$ & 35 & (1) Financial, (2) functional, (3) physical, (4) survey-based \\
\hline $\begin{array}{l}\text { Muchiri et al. } \\
\text { (2011) }\end{array}$ & Literature review & 31 & $\begin{array}{l}\text { (1) Leading (work identification, work planning, work scheduling and } \\
\text { work execution), (2) lagging (measures of equipment performance } \\
\text { and measures of cost performance) }\end{array}$ \\
\hline $\begin{array}{l}\text { Professional Retail } \\
\text { Store Maintenance } \\
\text { Association (2012) }\end{array}$ & $\begin{array}{l}\text { Interviews with mem- } \\
\text { bers of the Professional } \\
\text { Retail Store Mainte- } \\
\text { nance Association }\end{array}$ & 8 & (1) Financial, (2) functional, (3) directional \\
\hline $\begin{array}{l}\text { Rimbalová and } \\
\text { Vilčeková (2013) }\end{array}$ & Literature review & 37 & $\begin{array}{l}\text { (1) Economic, (2) social, (3) environment; with further classifications } \\
\text { according to impact on core business and relevance to FM services }\end{array}$ \\
\hline
\end{tabular}


indicators identified and categories to which the indicators belong.

Furthermore, Ho et al. (2000) in the FM field attempted to develop a set of performance metrics specific to the situation of the Asia Pacific region. Through questionnaire surveys, corporations in the region were asked to rate the importance levels of 97 metrics on a five-point scale and indicate if the metrics were being used in their FM practices. It was revealed that implementation of FM benchmarking was limited and awareness of the impact of FM on overall business was low. Besides, there were some empirical studies on KPIs. For example, Chan et al. (2001) carried out a case study on the maintenance performance of a hotel and the performance indicators investigated are: business availability; manpower utilization index; urgent repair request index; failure frequency; unit repairing time; preventive maintenance ratio; and energy use index.

In a bid to develop KPIs for evaluating O\&M performance of commercial buildings, the work of Lai and Yik (2006) found that the hurdles encountered include the knowledge, financial, motivation and information barriers of FM practitioners. With reference to that work, a matrix incorporating two essential dimensions, namely delivery process of facilities services and hierarchical level of an FM organization, was formed, in which some examples of indicators (Lai, Yik 2006) are also shown (Fig. 3). Based on this integrated process-hierarchy model, indicators can be identified for assessing input resource, delivery process and output performance of engineering facilities. Different FM staff, including those at the strategic, tactical and operational levels, can use the corresponding levels of indicators to evaluate the performance of facilities at different phases of their delivery processes. It is this model that serves as a keystone for developing the intended performance evaluation scheme under the current study.

\section{PERFORMANCE INDICATORS IDENTIFIED AND CATEGORIZED}

Based on the above review findings, 71 performance indicators were identified as applicable for measuring the performance of engineering facilities. To avoid redundancy and to enable effective management and reporting of performance, it is necessary to have proper categorization of the KPIs, which would help FM practitioners manage their facilities (Lavy et al. 2010).

Having considered the types of KPIs of various sources (British Standards Institution 2007; Gilleard, Wong 2004; Lavy et al. 2010; Muchiri et al. 2011; Parida, Chattopadhyay 2007; Professional Retail Store Maintenance Association 2012; Shohet 2006), a consolidated framework was constructed for classification of KPIs (Fig. 4). Under the framework, performance indicators are classified according to their functionalities and interpretations, and the main categories of indicators are: physical $(\mathrm{P})$, financial (F), task and equipment related $(\mathrm{T})$, environmental $(\mathrm{E})$, and health, safety and legal $(\mathrm{H})$.

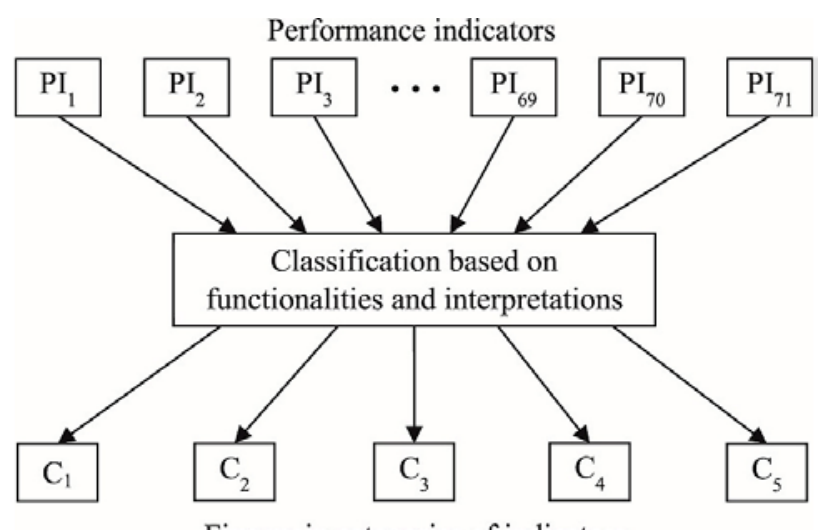

Five main categories of indicators

Fig. 4. Classification framework of performance indicators

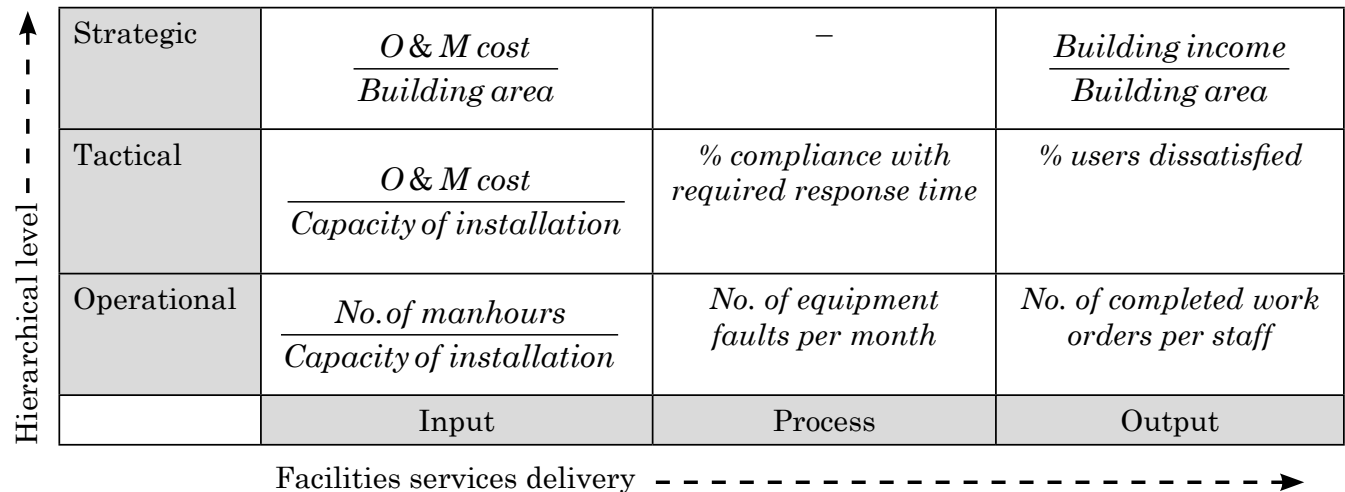

Fig. 3. An integrated process-hierarchy model for KPIs 


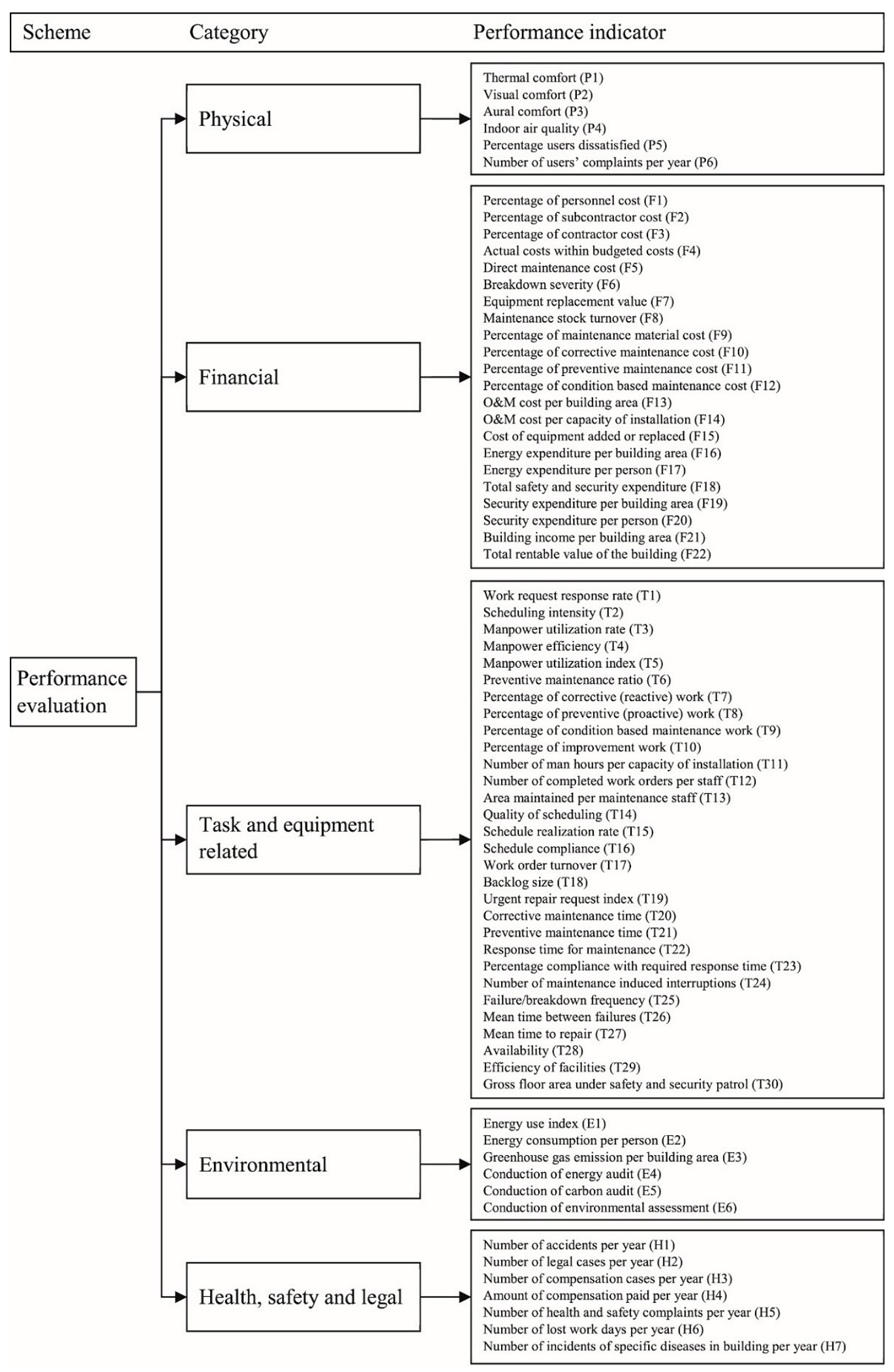

Fig. 5. A categorized summary of the performance indicators

Sources of the above indicators (British Standards Institution 2007; Building Services Research and Information Association 2004a, 2004b, 2011; Campbell 1995; Chan et al. 2001; Electrical and Mechanical Services Department 2007, 2012a; Electrical and Mechanical Services Department and Environmental Protection Department 2010; Hinks, McNay 1999; Ho et al. 2000; Hong Kong Quality Assurance Agency 2012b; Lai, Yik 2006; Lavy et al. 2010; Leung et al. 2005; Lützkendorf, Lorenz 2006; Muchiri et al. 2011; Parida, Chattopadhyay 2007; Professional Retail Store Maintenance Association 2012; Róka-Madarász 2011; Tsang et al. 1999; Vesela, Michael 2001). 
A categorized summary of the 71 indicators, grouped according to the framework in Figure 4, is shown in Figure 5. Among the five categories of indicators, there are six indicators in the physical category, 22 in the financial category, 30 in the task and equipment related category, six in the environmental group, and seven in the health, safety and legal group.

Physical performance of a commercial building could be measured by how well its builder's work (e.g. walls, windows) and building services systems (e.g. air-conditioning, lighting) are maintained. The eventual performance of such elements can refer to physical indicators P1 to P4: thermal comfort (e.g. temperature, mean radiant temperature, humidity and air speed), visual comfort (e.g. illuminance and glare), aural comfort (e.g. noise level, reverberation time) and indoor air quality (e.g. total volatile organic compound, $\mathrm{CO}_{2}$ level, concentration of radon). They collectively represent the physical quality of indoor environment resultant from the performance of the building's facilities. While reflecting the feelings or perceptions of end users, the levels of these physical indicators and/or those of the other two indicators, namely percentage users dissatisfied (P5) and number of users' complaints per year (P6), affect the users' satisfaction.

Factors affecting the financial indicators are related to expenditure, e.g. portion of cost incurred for hiring O\&M personnel (F1), total O\&M cost per area (F13) or part thereof such as cost for engaging contractors (F3), purchase of maintenance materials (F9), and so on. Disbursement for energy consumption (e.g. F16, F17), typically a significant cost item, also falls within this group of indicators. On the other side, revenues from rental income (e.g. F21, F22) are essential items in the financial account of a commercial building. Breakdown severity (F6), defined as the ratio of breakdown cost to direct maintenance cost, is an example of costeffectiveness indicators that measure how effective maintenance work is implemented for reducing facilities breakdown. Whereas cost efficiency indicators (e.g. ratio of expense to income), which require measurement of both resources input and outcome performance, have not been identified so far, the need of such indicators is to be further investigated in the next stages of work.

Task and equipment related indicators, which cover those that reflect the deployment of manpower such as utilization (T3) and efficiency (T4), the speediness of response to work requests (e.g. T22) or how frequent a facility breaks down (e.g. T 26), as well as the effectiveness of maintenance management in terms of scheduling (T14 to T16) and backlog (T18). Performance level of some critical facilities, e.g. availability of fire services system, is also among the equipment related indicators.

Energy use and greenhouse gas (or carbon) emission are major environmental issues. In the group of environmental indicators, energy use index (E1), energy consumption per person (E2) and greenhouse gas emission per building area (E3) are normalized indicators that measure the environmental impact of resources used for operating facilities in buildings. Another subgroup of environmental indicators consists of E4, E5 and E6. They show whether energy audit, carbon audit and environmental assessment are carried out, which in turn can help attain a sustainable built environment.

Health, safety and legal (HSL) indicators could show how well the FM team have done in safeguarding the health and safety of building occupants as well as their performance in avoiding legal costs arising from any mishaps of facilities operations. Amounts of accidents and legal cases (H1 and H2) and those of the associated compensation cases (H3 and $\mathrm{H} 4)$ indicate the consequential liability. The seriousness of HSL issues could also be reflected by indicators $\mathrm{H} 5$ and $\mathrm{H} 6$. Illnesses or even fatalities (e.g. due to Legionnaires' disease (LD), Middle East Respiratory Syndrome (MERS)) could be gauged by indicator $\mathrm{H} 7$.

\section{CONCLUSIONS}

Intended to develop a credible scheme for evaluating the performance of engineering facilities in existing commercial buildings, a four-stage study was carried out. This article is based on the findings from the literature review completed in Stage 1 of the study. It shows that among the essential requirements for a performance evaluation scheme, suitable indicators need to be identified for use in the scheme and they should be able to cover the important performance aspects of the facilities, enabling evaluations to be made at different levels of an FM organization.

Various efforts have been made in the past to develop performance evaluation schemes or identify KPIs for use in assessing the performance of built facilities. Yet a scheme tailored for evaluating the performance of engineering facilities in largescale commercial buildings, which is particularly needed for metropolises such as Hong Kong, was unavailable. Grounded on the literature review 
findings, a process-hierarchy model, in the form of a matrix incorporating both the FM organizational hierarchy (strategic, tactical and operational levels) and the mechanism of facilities services delivery (input, process and output phases), was established as a basis for identification of applicable performance indicators.

After consolidation, a total of 71 applicable indicators were classified according to their natures into five categories, namely physical, financial, task and equipment related, environmental, and health, safety and legal. But using all such indicators would incur considerable effort, outweighing the benefits obtainable from performance evaluation (Kumar 2006; Van Horenbeek, Pintelon 2014) and thus is practically unfeasible. Therefore it is necessary to shortlist the most essential indicators and assign weights to reflect their importance levels in order to establish the intended evaluation scheme for strategic use in managing real-world buildings.

\section{REFERENCES}

Amaratunga, D. 2000. Assessment of facilities management performance, Property Management 18(4): 258-266. https://doi.org/10.1108/02637470010348816

American Society for Testing and Materials International. 2009. ASTM standards for whole building functionality and serviceability. West Conshohocken, PA: American Society for Testing and Materials International.

Asian Institute of Intelligent Buildings. 2012. Intelligent Building Index (IBI) [online]. Asian Institute of Intelligent Buildings. Available at: http://www.aiib.net/ ibi-index.htm [accessed 25 November 2012]

Baird, G.; Gray, J.; Isaacs, N.; Kernohan, D.; McIndoe, G. 1995. Building evaluation techniques. Wellington, New Zealand: McGraw Hill.

Ballesty, S. 1999. Facility quality and performance, in R. Best; G. de Valence (Eds.). Building in value: predesign issues. London: Arnold Publishers, 198-211.

Best, R.; Langston, C.; de Valence, G. 2003. Workplace strategies and facilities management: building in value. Oxford: Butterworth-Heinemann.

Bluyssen, P. M. 2009. The indoor environment handbook: how to make buildings healthy and comfortable. New York: Routledge.

Bordass, B.; Leaman, A.; Ruyssevelt, P. 2001. Assessing building performance in use 5: conclusions and implications, Building Research \& Information 29(2): 144-157. https://doi.org/10.1080/09613210010008054

British Institute of Facilities Management. 2015. Facilities management introduction [online]. British Institute of Facilities Management. Available at: http:// www.bifm.org.uk/bifm/about/facilities [accessed 1 March 2015]
British Standards Institution. 2006. Facility management - part 1: terms and definitions (BS EN 152211:2006). London: British Standards Institution.

British Standards Institution. 2007. Maintenance: maintenance key performance indicators (BS EN 15341:2007). London: British Standards Institution.

British Standards Institution. 2009. Managing for the sustained success of an organization - a quality management approach (BS EN ISO 9004:2009). London: British Standards Institution.

British Standards Institution. 2011. Facility management - part 3: guidance on quality in facility management (BS EN 15221-3:2011). London: British Standards Institution.

British Standards Institution. 2012. Facility management - part 7: guidelines for performance benchmarking (BS EN 15221-7:2012). London: British Standards Institution.

Building Services Research and Information Association. 2004a. O\&M benchmarking network annual reportdefinitions booklet, Report 16225/2. UK: Building Services Research and Information Association.

Building Services Research and Information Association. 2004b. O\&M benchmarking network annual report, Report 16225/1. UK: Building Services Research and Information Association.

Building Services Research and Information Association. 2011. KPIs for M\&E contractors - 2010 results [online]. Building Services Research and Information Association. Available at: https://www.bsria.co.uk/news/ article/me-kpis-2010/ [accessed 25 November 2011]

Buildings Department. 2006a. Comprehensive environmental performance assessment scheme for buildings CEPAS application guidelines. Hong Kong: Buildings Department.

Buildings Department. 2006b. Comprehensive environmental performance assessment scheme for buildings construction stage assessment manual. Hong Kong: Buildings Department.

Buildings Department. 2006c. Comprehensive environmental performance assessment scheme for buildings design stage assessment manual. Hong Kong: Buildings Department.

Buildings Department. 2006d. Comprehensive environmental performance assessment scheme for buildings operation stage assessment manual. Hong Kong: Buildings Department.

Buildings Department. 2006e. Comprehensive environmental performance assessment scheme for buildings pre-design stage assessment manual. Hong Kong: Buildings Department.

Buildings Department. 2012. Comprehensive environmental performance assessment scheme for buildings [online]. Buildings Department. Available at: http:// www.bd.gov.hk/english/documents/index_CEPAS. html [accessed 15 September 2012]

Campbell, J. D. 1995. Uptime: strategies for excellence in maintenance management. New York: Productivity Press.

Carlucci, D. 2010. Evaluating and selecting key performance indicators: an ANP-based model, 
Measuring Business Excellence 14(2): 66-76. https://doi.org/10.1108/13683041011047876

Carpenter, C. L.; Oloufa, A. A. 1995. Postoccupancy evaluation of buildings and development of facility performance criteria, Journal of Architectural Engineering 1(2): 77-81. https://doi.org/10.1061/ (ASCE)1076-0431(1995)1:2(77)

Census and Statistics Department. 2015. Population [online]. Census and Statistics Department. Available at: http://www.censtatd.gov.hk/hkstat/sub/so20. jsp [accessed 2 April 2015]

Chan, A. P. C.; Chan, A. P. L. 2004. Key performance indicators for measuring construction success, Benchmarking: An International Journal 11(2): 203-221.

Chan, K. T.; Lee, R. H. K.; Burnett, J. 2001. Maintenance performance: a case study of hospitality engineering systems, Facilities 19(13/14): 494-504. https://doi.org/10.1108/02632770110409477

Chartered Institution of Building Services Engineers. 2015a. PROBE - post occupancy studies [online]. Chartered Institution of Building Services Engineers. Available at: http://www.cibse.org/knowledge/ building-services-case-studies/probe-post-occupancystudies [accessed 15 April 2015]

Chartered Institution of Building Services Engineers. 2015b. What is building services [online]. Chartered Institution of Building Services Engineers. Available at: http://www.cibse.org/building-services/what-isbuilding-services [accessed 2 April 2015]

Clift, M. 1996. Building quality assessment (BQA) for offices, Structural Survey 14(2): 22-25. https://doi.org/10.1108/02630809610122703

Cohen, R.; Standeven, M.; Bordass, B.; Leaman, A. 2001. Assessing building performance in use 1: the Probe process, Building Research \& Information 29(2): 85-102. https://doi.org/10.1080/09613210010008018

Davis, G.; Thatcher, C.; Blair, L. 1993a. Serviceability tools: methods for setting occupant requirements and rating buildings. Ottawa: International Centre for Facilities.

Davis, G.; Thatcher, C.; Blair, L. 1993b. Serviceability tools: scales for setting occupant requirements and rating buildings. Ottawa: International Centre for Facilities.

Electrical and Mechanical Services Department and Environmental Protection Department. 2010. Guidelines to account for and report on greenhouse gas emissions and removals for buildings (commercial, residential or institutional purposes) in Hong Kong. Hong Kong: Electrical and Mechanical Services Department, Environmental Protection Department.

Electrical and Mechanical Services Department. 2007. Guidelines on energy audit. Hong Kong: Electrical and Mechanical Services Department.

Electrical and Mechanical Services Department. 2012a. Code of practice for building energy audit. Hong Kong: Electrical and Mechanical Services Department.

Electrical and Mechanical Services Department. 2012b. Code of practice for energy efficiency of building services installation. Hong Kong: Electrical and $\mathrm{Me}$ chanical Services Department.
Electrical and Mechanical Services Department. 2012c. Energy end-use data and consumption indicators/ benchmarking tools: energy consumption indicators \& benchmarking tools [online]. Electrical and Mechanical Services Department. Available at: http://www.emsd.gov.hk/emsd/eng/pee/ecib.shtml [accessed 15 October 2012]

Electrical and Mechanical Services Department. 2012d. HK energy efficiency registration scheme for buildings [online]. Electrical and Mechanical Services Department. Available at: http://www.emsd.gov.hk/emsd/ eng/pee/eersb.shtml [accessed 15 October 2012]

Gilleard, J. D.; Wong, P. Y. L. 2004. Benchmarking facility management: applying analytic hierarchy process, Facilities 22(1): 19-25.

https://doi.org/10.1108/02632770410517915

Göçer, Ö.; Hua, Y.; Göçer, K. 2015. Completing the missing link in building design process: enhancing post-occupancy evaluation method for effective feedback for building performance, Buildng and Environment 89: 14-27. https://doi.org/10.1016/j.buildenv.2015.02.011

Haktanir, M.; Harris, P. 2005. Performance measurement practice in an independent hotel context: a case study approach, International Journal of Contemporary Hospitality Management 17(1): 39-50. https://doi.org/10.1108/09596110510577662

Hinks, J.; McNay, P. 1999. The creation of a management-by-variance tool for facilities management performance assessment, Facilities 17(1/2): 31-53. https://doi.org/10.1108/02632779910248893

Ho, D. C. W.; Chan, E. H. W.; Wong, N. Y.; Chan, M. W. 2000. Significant metrics for facilities management benchmarking in the Asia Pacific region, Facilities 18(13): 545-556.

https://doi.org/10.1108/02632770010358088

Ho, D. C. W.; Chau, K. W.; Yau, Y.; Cheung, A. K. C.; Wong, S. K. 2005. Comparative study of building performance assessment schemes in Hong Kong, Hong Kong Surveyor 16(1): 47-58.

Ho, D. C. W.; Yau, Y. 2004. Building safety and condition index: benchmarking tool for maintenance managers, in Proceedings of the CIB W70 Facilities Management and Maintenance Symposium 2004, 7-8 December 2004, Hong Kong, 149-155.

Hong Kong Green Building Council. 2012a. BEAM Plus for existing buildings, Version 1.2. Hong Kong: Hong Kong Green Building Council.

Hong Kong Green Building Council. 2012b. BEAM Plus for new buildings, Version 1.2. Hong Kong: Hong Kong Green Building Council.

Hong Kong Quality Assurance Agency. 2012a. HKQAA sustainable building index [online]. Hong Kong Quality Assurance Agency. Available at: http://www. hkqaa.org/en_winestorage.php?catid=4 [accessed 2 August 2012]

Hong Kong Quality Assurance Agency. 2012b. HKQAA sustainable building index report template and metrics handbook. Hong Kong: Hong Kong Quality Assurance Agency.

Hong Kong Tourism Board. 2013. Overnight visitors to Hong Kong up 6.5\% in 2012 [online]. Hong Kong 
Tourism Board. Available at: http://partnernet.hktb. com/filemanager/pressrelease/Tourism\%20Stat\%20 12\%202012.pdf [accessed 29 March 2013]

Hopfe, C. J.; Augenbroe, G.; Hensen, J. L. M. 2013. Multi-criteria decision making under uncertainty in building performance assessment, Buildng and Environment 69: 87-90. https://doi.org/10.1016/j.buildenv.2013.07.019

Ingram, H.; Daskalakis, G. 1999. Measuring quality gaps in hotels: the case of Crete, International Journal of Contemporary Hospitality Management 11(1): 24-30. https://doi.org/10.1108/09596119910250364

Innovate UK. 2015. Building performance evaluation [online]. Innovate UK. Available at: https://connect. innovateuk.org/web/building-performance-evaluation/tools-and-methods [accessed 18 June 2015]

International Centre for Facilities. 2000. Use the serviceability tools and methods for productive and cost-effective workplaces [online]. International Centre for Facilities. Available at: http://www.icf-cebe.com/tools/ what_is_stm.pdf [accessed 1 June 2015]

International Facility Management Association. 2015. What is FM [online]. International Facility Management Association. Available at: http://www.ifma.org/ know-base/browse/what-is-fm- [accessed 1 March 2015]

Kincaid, D. G. 1994. Measuring performance in facilities management, Facilities 12(6): 17-20. https://doi.org/10.1108/02632779410060265

Koleoso, H.; Omirin, M.; Adewunmi, Y.; Babawale, G. 2013. Applicability of existing performance evaluation tools and concepts to the Nigerian facilities management practice, Internation Journal of Strategic Property Management 17(4): 361-376. https://doi.org/10.3846/1648715X.2013.861367

Kumar, U. 2006. Development and implementation of maintenance performance measurement system: issues and challenges, in J. Mathew; J. Kennedy; L. Ma; D. Tan; D. Anderson (Eds.) Engineering and management. London: Springer, 738-743. https://doi.org/10.1007/978-1-84628-814-2_78

Kutucuoglu, K. Y.; Hamali, J.; Irani, Z.; Sharp, J. L. 2001. A framework for managing maintenance using performance measurement system, International Journal of Operations \& Production Management 21(1/2): 173-194. https://doi.org/10.1108/01443570110358521

Lai, J. H. K. 2010. Operation and maintenance budgeting for commercial buildings in Hong Kong, Construction Management and Economics 28: 415-427. https://doi.org/10.1080/01446190903365665

Lai, J. H. K. 2012. Analytical assessment and comparison of facilities management services for residential estates, Internation Journal of Strategic Property Management 16(3): 236-253. https://doi.org/10.3846 /1648715X.2012.682183

Lai, J. H. K. 2014. Maintenance performance: examination of the computer-aided maintenance data of a large commercial building, Journal of Performance of Constructed Facilities 29(4): 04014118. https://doi. org/10.1061/(ASCE)CF.1943-5509.0000619

Lai, J. H. K.; Choi, E. C. K. 2015. Performance measurement for teaching hotels: a hierarchical system incor- porating facilities management, Journal of Hospitality, Leisure, Sport \& Tourism Education 16: 48-58. https://doi.org/10.1016/j.jhlste.2015.02.002

Lai, J. H. K.; Yik, F. W. H. 2006. Developing performance indicators for benchmarking building services operation and maintenance for commercial buildings, in Proceedings of CIBW70 Trondheim International Symposium: Changing User Demands on Buildings, 12-14 June 2006, Trondheim, Norway, 283-294.

Lai, J. H. K.; Yik, F. W. H. 2008. Benchmarking operation and maintenance costs of luxury hotels, Journal of Facilities Management 6(4): 279-289. https://doi.org/10.1108/14725960810908145

Lai, J. H. K.; Yik, F. W. H. 2011. An analytical method to evaluate facility management services for residential buildings, Building and Environment 46(1): 165-175. https://doi.org/10.1016/j.buildenv.2010.07.012

Lai, J. H. K.; Yik, F. W. H. 2012. Hotel engineering facilities: a case study of maintenance performance, International Journal of Hospitality Management 31(1): 229-235. https://doi.org/10.1016/j.ijhm.2011.05.002

Lai, J. H. K.; Yik, F. W. H.; Jones, P. 2008. Expenditure on operation and maintenance service and rental income of commercial buildings, Facilities 26(5/9): 242-265. https://doi.org/10.1108/02632770810865014

Lavy, S.; Garcia, J. A.; Dixit, M. K. 2010. Establishment of KPIs for facilities performance measurement: review of literature, Facilities 18(9/10): 440-464. https://doi.org/10.1108/02632771011057189

Lavy, S.; Garcia, J. A.; Manish, K. D. 2014a. KPIs for facility's performance assessment, part I: identification and categorization of core indicators, Facilities 32(5/6): 256-274. https://doi.org/10.1108/F-09-2012-0066

Lavy, S.; Garcia, J. A.; Manish, K. D. 2014b. KPIs for facility's performance assessment, part II: identification of variables and deriving expressions for core indicators, Facilities 32(5/6): 275-294.

https://doi.org/10.1108/F-09-2012-0067

Lavy, S.; Shohet, L. M. 2007. A strategic integrated healthcare facility management model, International Journal of Strategic Property Management 11(3): 125-142.

Leung, M. Y.; Lu, X.; Ip, H. Y. 2005. Investigating key components of the facility management of secondary schools in Hong Kong, Facilities 23(5): 226-238. https://doi.org/10.1108/02632770510588637

Loosemore, M.; Hsin, Y. Y. 2001. Customer-focused benchmarking for facilities management, $F a$ cilities 19(13): 464-475. https://doi.org/10.1108/ EUM0000000006204

Lützkendorf, T.; Lorenz, D. P. 2006. Using an integrated performance approach in building assessment tools, Building Research \& Information 34(4): 334-356. https://doi.org/10.1080/09613210600672914

Man, C. S.; Lai, J. H. K.; Yik, F. W. H. 2012. A review of the green building assessment methods of the US, UK, China and Hong Kong, in Proceedings of the $3^{\text {rd }}$ Greater Pearl River Delta Conference on Building Operation and Maintenance, 10 November 2012, Guangzhou, China, 29-40.

Man, C. S.; Lai, J. H. K.; Yik, F. W. H. 2013. Developing a research framework for studying performance 
evaluation of engineering facilities in commercial buildings in Hong Kong, in S. Kajewski; K. Manley; K. Hampson (Eds.). Proceedings of the $19^{\text {th }}$ International CIB World Building Congress, 5-9 May 2013, Queensland University of Technology, Brisbane, Australia.

Martinez, V.; Kennerley, M.; Neely, A. 2004. Impact of PMS on business performance: a methodological approach. Bedfordshire: Centre for Business Performance, Cranfield School of Management, 1-15.

McDougall, G.; Kelly, J. R.; Hinks, J.; Bititci, U. S. 2002. A review of the leading performance measurement tools for assessing buildings, Journal of Facilities Management 1(2): 142-153.

https://doi.org/10.1108/14725960310807881

Min, H.; Min, H. 1996. Competitive benchmarking of Korean luxury hotels using the analytic hierarchy process and competitive gap analysis, Journal of Services Marketing 10(3): 58-72.

https://doi.org/10.1108/08876049610119794

Min, H.; Min, H. 1997. Benchmarking the quality of hotel services: managerial perspectives, International Journal of Quality \& Reliability Management 14(6): 582-597. https://doi.org/10.1108/02656719710186209

Min, H.; Min, H.; Chung, K. 2002. Dynamic benchmarking of hotel service quality, Journal of Services Marketing 16(4): 302-321. https://doi.org/10.1108/08876040210433211

Muchiri, P.; Pintelon, L.; Gelders, L.; Martin, H. 2011. Development of maintenance function performance measurement framework and indicators, International Journal of Production Economics 131(1): 295302. https://doi.org/10.1016/j.ijpe.2010.04.039

Myeda, N. E.; Kamaruzzaman, S. N.; Pitt, M. 2011. Measuring the performance of office buildings maintenance management in Malaysia, Journal of Facilities Management 9(3): 181-199. https://doi.org/10.1108/14725961111148090

Najmi, M.; Rigas, J.; Fan, I. S. 2005. A framework to review performance measurement systems, Business Process Management Journal 11(2): 109-122. https://doi.org/10.1108/14637150510591129

Neely, A.; Gregory, M.; Platts, K. 1995. Performance measurement system design: a literature review and research agenda, International Journal of $\mathrm{Op}$ erations \& Production Management 15(4): 80-116. https://doi.org/10.1108/01443579510083622

Parida, A.; Chattopadhyay, G. 2007. Methodology and theory - development of a multi-criteria hierarchical framework for maintenance measurement (MPM), Journal of Quality in Maintenance 13(3): 241-258. https://doi.org/10.1108/13552510710780276

Parida, A.; Kumar, U. 2006. Applications and case studies - maintenance performance measurement (MPM): issues and challenges, Journal of Quality in Maintenance Engineering 12(3): 239-251. https://doi.org/10.1108/13552510610685084

Pati, D.; Park, C. S.; Augenbroe, G. 2009. Roles of quantified expressions of building performance assessment in facility procurement and management, Building and Environment 44(4): 773-784. https://doi.org/10.1016/j.buildenv.2008.06.018
Preiser, W.; Rabinowitz, H.; White, E. T. 1988. Postoccupancy evaluation. New York: Van Nostrand Reinhold Company.

Prill, R.; Kunkle, R.; Novosel, D. 2009. Development of an operation and maintenance rating system for commercial buildings. USA: National Center for Energy Management and Building Technologies.

Professional Retail Store Maintenance Association. 2012. KPI applications in retail facilities management - best practices white paper. Dallas, Texas: Professional Retail Store Maintenance Association.

Rashvand, P.; Majid, M. Z. A. 2014. Critical criteria on client and customer satisfaction for the issue of performance measurement, Journal of Management in Engineering 30(1): 10-18. https://doi.org/10.1061/ (ASCE)ME.1943-5479.0000183

Rating and Valuation Department. 2014. Hong Kong property review 2014. Hong Kong: Rating and Valuation Department.

Rimbalová, J.; Vilčeková, S. 2013. The proposal of key performance indicators in facilities management and determination the weights of significance, Journal of Civil Engineering 8(2): 73-84. https://doi.org/10.2478/ sspjce-2013-0020

Riratanaphong, C.; Van der Voordt, T. J. M. 2014. Measuring the added value of workplace change: comparison between theory and practice, in Proceedings of CIB Facilities Management Conference: Using facilities in an open world creating value for all stakeholders, 21-23 May 2014, Copenhagen, Denmark, 94-105.

Róka-Madarász, L. 2011. Performance measurement for maintenance management of real estate, Acta Polytechnica Hungarica 8(1): 161-172.

Shohet, I. M. 2006. Key performance indicators for strategic healthcare facilities maintenance, Journal of Construction Engineering and Management 132(4): 345-352. https://doi.org/10.1061/(ASCE)07339364(2006)132:4(345)

Stevens, J. D.; Glagoia, C.; Ledbetter, W. B. 1994. Quality-measuremnt matrix, Journal of Management in Engineering 10(6): 30-35. https://doi.org/10.1061/ (ASCE)9742-597X(1994)10:6(30)

Szigeti, F.; Davis, G. 2001. Matching people and their facilities: using the ASTM/ANSI standards on whole building functionality and serviceability, in Proceedings of CIB World Building Congress, April 2001, Wellington, New Zealand. Available at: http:// www.icf-cebe.com/cib/papers/icf\%20szigeti_davis_paper_99_cib2001.pdf [accessed 1 June 2015]

Szigeti, F.; Davis, G. 2005. Performance based building: conceptual framework [online]. CIBdf. Available at: http://www.pebbu.nl/resources/allreports/downloads/04_framework_final.pdf [accessed 10 June 2015]

The Government of the Hong Kong Special Administrative Region. 2015. Hong Kong - the facts, geography [online]. The Government of the Hong Kong Special Administrative Region. Available at: http://www. gov.hk/en/about/abouthk/facts.htm [accessed 2 April 2015] 
Then, D. S. S. 2005. A proactive property management model that integrates real estate provision and facilities services management, Internation Journal of Strategic Property Management 9(1): 33-42.

Then, D. S. S.; Tan, T. H.; Chau, C. K. 2004. An intergrated asset performance framework for operational buildings - preliminary results of focus group validations in Hong Kong and Australia, in Proceedings of CIB W70 2004 Hong Kong International Symposium - Human Elements in Facilities Management, 7-8 December 2004, CIB Publication No. 297. Hong Kong, 239-250.

Thor, C. G. 1991. Performance measurement in a research organization, National Productivity Review 10(4): 499-507. https://doi.org/10.1002/ npr.4040100407

Training Resources and Data Exchange. 1995. How to measure performance: a handbook of techniques and tools. U.S. Department of Energy.

Tsang, A. H. C.; Jardine, A. K. S.; Kolodny, H. 1999. Measuring maintenance performance: a holistic approach, International Journal of Operations \& Production Management 19(7): 691-715. https://doi.org/10.1108/01443579910271674
Van Horenbeek, A.; Pintelon, L. 2014. Development of a maintenance performance measurement framework - using the analytic network process (ANP) for maintenance performance indicator selection, Omega 42(1): 33-46. https://doi.org/10.1016/j.omega.2013.02.006

Vesela, V.; Michael, E. 2001. Indicators of sustainable production: framework and methodology, Journal of Cleaner Production 9: 519-549. https://doi.org/10.1016/S0959-6526(01)00010-5

Webster, C.; Hung, L. C. 1994. Measuring service quality and promoting decentring, The TQM Magazine 6(5): 50-55. https://doi.org/10.1108/09544789410067871

Yusof, N. A.; Abdullah, S.; Mohd Najib, N. U. 2014. How does communication influence the perceived performance of maintenance services on multi-storey public housing?, Internation Journal of Strategic Property Management 18(4): 380-392. https://doi.org/10. 3846/1648715X.2014.971918

Zimring, C. 2014. Facility performance evaluation (FPE) [online]. Washington, DC: National Institute of Building Sciences (NIBS). Available at: http://www. wbdg.org/resources/fpe.php [accessed 18 April 2015] 